\title{
Who will make the trip to Mars?
}

President George Bush's plans for Mars will disappoint the enthusiasts, but they will not send the value of the US dollar into decline, for which everybody should be thankful.

LAST Thursday's celebration, at the Air and Space Museum in Washington, of the twentieth anniversary of Apollo 11's landing on the Moon found President George Bush in typical laconic and noncommittal speech. "This vision thing" - Bush's phrase in another context for uplifting views of what the future holds - was more evident in what three lunar astronauts had to say than in his own address. True, there were some positive declarations - "We must commit ourselves anew to a sustained program of manned exploration of the Solar System and, yes, the permanent settlement of space", for example but their delivery was flat. Worse, there was no timetable. Bush properly made it plain that that decision rests with US Congress and its capacity to appropriate the funds. Both Bush and the Congress now know that getting to Mars is not a technical but a financial problem.

Comparisons with President John F. Kennedy's wellsounding launch of the Apollo programme are inevitable, inevitably invidious, but illuminating as well. Kennedy's goal was an adventure that would demonstrate the quality of US technology and also set a milestone in the track of human history. Apollo was a huge risk. When the United States was still smarting from the unexpected success of the Soviet Sputniks, it was a firm commitment to reach the Moon within a decade. What would have happened if the technology had failed? Or if the cost of making it work had exceeded the estimated cost of $\$ 20,000$ million? Kennedy implied that the United States was strong enough to take the risk and to pay whatever bills accrued. Early in the 1960s, that was true. Even the commitment to Apollo made the people of the United States feel good. The success of the project less than a decade later would have been permanently uplifting if, by then, the US commitment in South Vietnam had not proved socially divisive and financially debilitating.

Sadly, as Bush knows, things are different now. Japanese technology now has the edge, although not decisively, while the US federal budget deficit means that the Congress has hardly any room in which to find the cost of the few hundred thousand million dollars that an expedition to Mars will cost. If Bush last Thursday had said that an "American will walk on Mars by $20 \mathrm{XX}$ ", he would have instantly have undermined the patient efforts of Mr Alan Greenspan and the Federal Reserve to walk the tightrope between inflation and recession and would have sent the value of the US dollar tumbling. Bush, in the circumstances, did the most he could: there will be US astronauts on Mars when the cost has been calculated accurately and when the United States can afford it.

The disappointment in last week's declaration is, or should be, more subtle. By citing only historical inevitability as the reason why US citizens should go to Mars, Bush has begged a long list of questions. What part will be played in this new adventure by the Soviet Union and, as the decades roll by, by Japan? Will the technical demands of the enterprise so stiffen and stimulate now-bankrupt public education in the United States as to meet the needs of civilian industry for skill, or alternatively further divert what skill there is from useful and profitable enterprises? And what is it for?

The plain truth is that there are less risky, cheaper and more productive alternatives to what is now proposed. First, just within grasp, is the Hubble Space Telescope, still on the ground at Los Angeles, which will certainly clarify and may well transform our picture of how the Universe is constructed. Does it make sense that such a potential transformant of the human imagination should continue to wait on the vagaries of the shuttle's schedule? And what of the imaginative proposal for an international centre in astrophysics (see Nature 339, 574; 22 June 1989) being canvassed by astronomers and space scientists from the United States, the Soviet Union and elsewhere? Instruments will tell us what it is like to walk on Mars long before people can get there: would it not be more valuable to know what the whole Universe is like? Sober enterprises like these would help enormously to restore the world's faith in science and technology as a means to understanding.

\section{Europe and Japan}

The British House of Lords has made a perceptive comment on relations between Europe and Japan.

EuROPE, hugging itself with pleasure that it will be a true common market by the end of 1992, is nevertheless scared stiff of the prospect of ruinous technological competition with Japan. So much is clear from the ways in which the European Communities (EC) and individual member states have sought over the years to protect themselves. Many European states have enacted compulsory quotas 